University of Nebraska - Lincoln

DigitalCommons@University of Nebraska - Lincoln

Nebraska Cooperative Fish \& Wildlife Research Nebraska Cooperative Fish \& Wildlife Research Unit -- Staff Publications

2004

\title{
Effect of catch-and-release angling on growth of largemouth bass, Micropterus salmoides
}

\author{
K. L. Pope \\ Texas Tech University, kpope2@unl.edu \\ G. R. Wilde \\ Texas Tech University
}

Follow this and additional works at: https://digitalcommons.unl.edu/ncfwrustaff

Part of the Other Environmental Sciences Commons

Pope, K. L. and Wilde, G. R., "Effect of catch-and-release angling on growth of largemouth bass, Micropterus salmoides" (2004). Nebraska Cooperative Fish \& Wildlife Research Unit -- Staff Publications. 63.

https://digitalcommons.unl.edu/ncfwrustaff/63

This Article is brought to you for free and open access by the Nebraska Cooperative Fish \& Wildlife Research Unit at DigitalCommons@University of Nebraska - Lincoln. It has been accepted for inclusion in Nebraska Cooperative Fish \& Wildlife Research Unit -- Staff Publications by an authorized administrator of DigitalCommons@University of Nebraska - Lincoln. 


\title{
Effect of catch-and-release angling on growth of largemouth bass, Micropterus salmoides
}

\author{
K. L. POPE \& G.R. WILDE \\ Wildlife and Fisheries Management Institute, Texas Tech University, Lubbock, TX, USA
}

\begin{abstract}
Catch-and-release angling is popular in many parts of the world and plays an increasingly important role in management of recreational fisheries. Although the magnitude of catch-and-release mortality is well documented for many species, potential sublethal effects have been little studied. An experiment was conducted to assess directly the effects of catch-and-release angling on growth of largemouth bass, Micropterus salmoides Lacépède. Angling mortality was $0.00 \pm 0.092 \%$ for largemouth bass caught on plastic grubs. There was no difference $(P=0.57)$ in weight gain between caught and uncaught fish over a 40 -day angling and recovery period. Although catch-and-release angling appears to have no effect on largemouth bass growth, previous studies documented sublethal effects on growth and reproduction in other species, suggesting that the occurrence and magnitude of sublethal effects vary among species.
\end{abstract}

KEYWORDS: angling effects, growth, Micropterus salmoides, weight.

\section{Introduction}

Catch-and-release angling has increased in popularity in many places such as the United States of America (Barnhart 1989; Muoneke \& Childress 1994), Australia (McLeay, Jones \& Ward 2002) and Europe (Aas, Thaling \& Ditton 2002) and plays an increasingly important role in fishery management (Hickley, Marsh \& North 1995; Maitland 1995; Quinn 1996). The increase in catch-and-release angling has occurred for two primary reasons. First, many anglers practice catch and release as a conservation measure, to maintain fishery quality. Secondly, as fishery resources are finite, yet angler effort continues to increase, fishery managers increasingly are using restrictive length and bag (creel) limits to protect the viability of fish stocks. These regulations may require anglers to release fish of certain sizes or those in excess of some bag or possession limit. The success of catch-and-release angling to meet various angler and management goals requires that a substantial proportion of fish survive capture and release (Muoneke \& Childress 1994).

Numerous studies have examined mortality of fish that are captured and released by recreational (Muoneke \& Childress 1994) and tournament anglers (Wilde 1998). Total mortality of fishes captured and released by anglers is influenced by a number of factors, primarily temperature and hooking location, and is generally only considered excessive and deserving of management attention when it exceeds 20\% (Muoneke \& Childress 1994). Although the magnitude of catchand-release mortality is well documented for many species, potential sublethal effects of catch-and-release angling are less studied. The physiological responses of fish to stresses associated with capture, handling, air exposure, and release were described by Wydoski (1977), Gustaveson, Wydoski \& Wedemeyer (1991) and Cooke, Schreer, Wahl \& Philipp (2002). However, only one study (Raat, Klein, Breteler \& Jansen 1997) directly examined the potential effects on growth of catch-and-release angling. In this paper, results of an experiment designed to assess the effects of catch-andrelease angling on growth of largemouth bass, Micropterus salmoides Lacépède are reported. Because catchand-release mortality is temperature dependent (Wilde 1998; Wilde, Muoneke, Bettoli, Nelson \& Hysmith 2000), the experiment was conducted during the summer when the greatest possible effects would be expected.

\section{Materials and methods}

One hundred and eleven largemouth bass $(20-38-\mathrm{cm}$ total length, TL) were collected from Lake Alan 
Henry, Texas using electric fishing (pulsed DC) on 9 May 2002. These fish were used only in this experiment. Fish were transported in aerated tanks to Texas Tech University. The fish were anesthetized $\left(0.1 \mathrm{~g} \mathrm{MS}-222 \mathrm{~L}^{-1}\right.$ water), implanted with passive integrative transponder (PIT) tags following the methods of Prentice, Hernandez, Shaw \& Wienecke (1991), TL measured (nearest $\mathrm{mm}$ ), weighed (nearest $\mathrm{g}$ ), and placed into one of four replicate 4167-L circular tanks (3.4-m diameter $\times 0.6-\mathrm{m}$ depth). Fish were sorted into tanks based on length to prevent cannibalism and minimize other size-related behaviours. Largemouth bass were allowed to acclimate to the tanks for 9 days during which time 10 fish died; this resulted in a final sample of 101 fish distributed among the four tanks. Sample size and mean length for each tank were tank $1, n=26, \mathrm{TL} \pm \mathrm{SE}=231 \pm 3 \mathrm{~mm}$; tank $2, n=26, \mathrm{TL} \pm \mathrm{SE}=261 \pm 2 \mathrm{~mm}$; tank $3, n=25$, $\mathrm{TL} \pm \mathrm{SE}=282 \pm 1 \mathrm{~mm} ; \quad$ and tank $4, \quad n=24$, $\mathrm{TL} \pm \mathrm{SE}=313 \pm 4 \mathrm{~mm}$.

Angling in each tank began on 18 May 2002. A $1.8-\mathrm{m}$, medium-action bait-casting rod with $5.4-\mathrm{kg}$ test line that was baited with a $10-\mathrm{cm}$ plastic grub (Mister Twister ${ }^{\circledR}$ Twister Grub) was used. The bait was chartreuse and was rigged with a 2/0-barbed worm-hook without a weight. This bait was selected because its action is unhindered by use in small areas. The goal was to catch 16 individual largemouth bass in each tank (a total of 64 caught fish; Fig. 1), leaving approximately nine fish in each tank to serve as controls. Efforts to capture fish in each tank were continued until 16 fish in a tank were captured or until 11 June 2002. Once a fish was hooked, it was played (mean play time $=17 \mathrm{~s}$, $\mathrm{SE}=1.5 \mathrm{~s}, n=25$ ) until it could easily be handled by grasping the lower jaw. Captured fish were removed from the water (mean time out of water $=25 \mathrm{~s}, \mathrm{SE}=2.6 \mathrm{~s}, n=25)$, the hook was removed using needle-nose pliers and the fish was scanned with a PIT-tag reader to identify the individual caught. Each fish was returned to the tank from which it was captured, and the PIT tag number, anatomical location of hooking, occurrence of bleeding, and time of capture were recorded.

The assessment period was 40 days, which provided sufficient time to assess growth after fish were caught and released. Largemouth bass were fed every 1-4 days depending on how quickly they consumed introduced prey at their last feeding. The goal of feeding was to provide $2-3 \%$ of body weight per day, a feeding rate that is sufficient for fish growth (Stickney 1979). Prey included plains killifishes, Fundulus zebrinus Jordan \& Gilbert, minnows Cyprinidae, sunfishes,

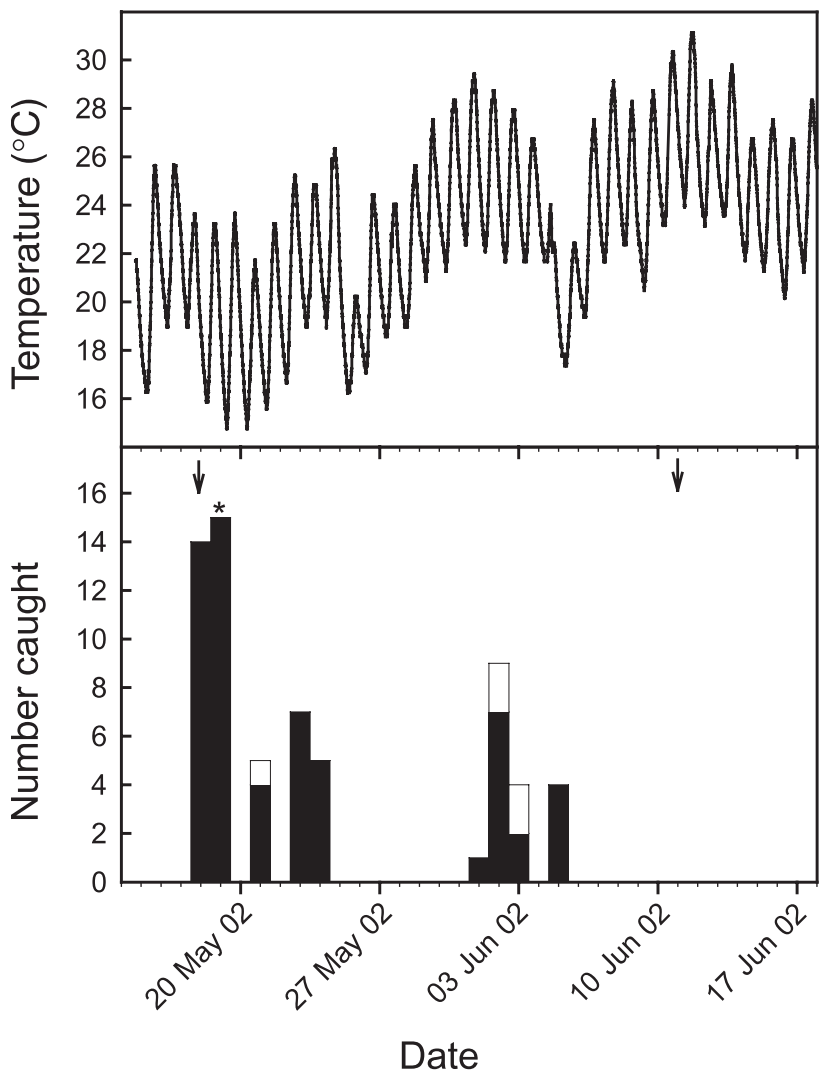

Figure 1. Water temperature (top panel) and number of largemouth bass caught by day (bottom panel) during a 40-day catch-and-release angling experiment. Solid bars indicate first capture of fish; open bars indicate second capture of fish. The arrows denote the beginning and ending dates of angling. The asterisk identifies the date of capture for one caught fish that died during the experiment.

Lepomis spp., inland silverside, Menidia beryllina (Cope), mosquitofish, Gambusia affinis (Baird \& Girard), and gizzard shad, Dorosoma cepedianum (LeSueur) and were sorted into tanks based on size (i.e. larger prey were fed to the larger largemouth bass). Each tank was aerated with a $3030-\mathrm{L} \mathrm{h}^{-1}$ powerhead, and $18-45 \%$, by volume, of water was replaced daily to maintain suitable water quality. Water and air temperature was recorded every $15 \mathrm{~min}$ using $\mathrm{HOBO}{ }^{\circledR}$ Temp data loggers (Onset Computer Corporation, Pocasset, MA, USA). During the experiment air temperature ranged from 8.6 to $37.8^{\circ} \mathrm{C}$ and water temperature ranged from 14.8 to $31.1^{\circ} \mathrm{C}$ (Fig. 1).

After angling ended on 11 June 2002, largemouth bass were held and fed for 7 days. After this period, fish were removed from each tank and identified by PIT tag, and final lengths and weights were measured and recorded. Growth of individual largemouth bass was assessed as the difference between final and initial 
weights over the 40-day experimental period. Captured largemouth bass were allowed to recover from hooking for an average of 24 (range $=10-31$ ) days.

For statistical analysis, tanks were treated as blocks and individual fish as the experimental unit. The experimental design purposefully confounded tank and length effects to allow potential effects of catch-andrelease angling on growth to be estimated without using length, or other measure of size, as a covariate. Analysis of variance was used to assess differences in growth between caught and uncaught fish and among blocks. Data were normally distributed and, therefore, were not transformed. Because sample size varied among tanks and, especially, between caught and uncaught fish, Type III sums of squares was used. Statistical significance was set at $\alpha=0.05$.

\section{Results}

Of 101 largemouth bass in the tanks when angling began, only two uncaught $(4.8 \%)$ and one caught fish $(1.7 \%)$ died; therefore, following Wilde, Pope \& Strauss (2003), angling mortality was considered $0.00 \pm 0.092 \%$ (i.e. no difference in mortality between caught and control fish was detected). Largemouth bass were hooked in a number of locations (Fig. 2), but most were hooked in the upper maxilla $(37 \%)$, lower mandible $(17 \%)$, roof of the mouth $(29 \%)$ and inside the cheek $(14 \%)$. One fish $(2 \%)$ was hooked in

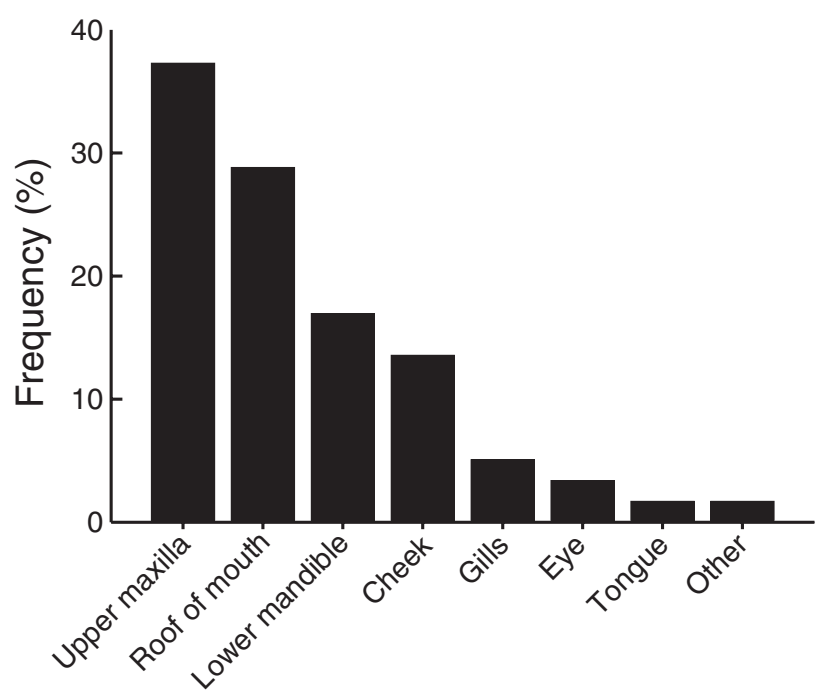

Hooking location

Figure 2. Frequency histogram of hooking locations for captured largemouth bass. Summed frequencies are $>100 \%$ because five fish were captured twice.

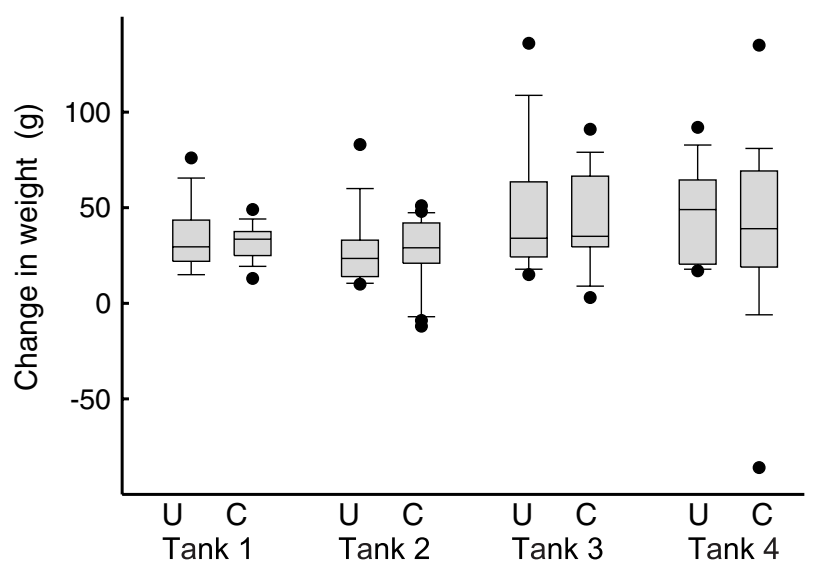

Figure 3. Box plots showing differences in growth of largemouth bass, as measured by increases in weight. The shaded box encloses the 25 th and 75 th percentiles, the vertical bars denote the 5 th and 95 th percentile, the sample median is represented by the horizontal line in each box and outliers are denoted by dots. Results are plotted separately for caught (C) and uncaught (U) largemouth bass in each of the four tanks. The asymmetry in data distributions is likely an artefact of small sample sizes for each data set. Fish were assigned to tanks based on initial length, with shortest fish assigned to tank 1 and longest fish to tank 4 .

the eye and blinded. Three per cent of captured fish were observed to bleed after hooking.

Overall, there was no difference in growth of caught and uncaught largemouth bass, as measured by increased weight (Fig. 3). Weight gain generally increased with initial length among uncaught (mean weight gain in the four tanks, in order of increasing initial length $=35.3,28.6,46.1$ and $48.1 \mathrm{~g}$ ) and caught fish (mean $=31.8,27.6,40.5$ and $44.7 \mathrm{~g}$ ). There was no significant difference in weight gain among tanks $(P=0.11)$ or between caught and uncaught fish $(P=0.57)$.

\section{Discussion}

The results suggest an angling mortality of $0.00 \pm 0.09 \%$ for largemouth bass caught on plastic grubs. This is consistent with mortality rates of $2-3 \%$ observed by Plumb, Grizzle \& Rogers (1988) and Mankin, Burkett, Beaty, Childers \& Philipp (1984); however, this mortality rate is much less than the $22 \%$ reported by Myers \& Poarch (2000) and 38\% reported Rutledge \& Pritchard (1977). Angling mortality of largemouth bass varies with the anatomical location in which the fish is hooked (May 1972; Pelzman 1978). All of the fish captured in the present study were hooked in locations for which mortality is generally low $(<2 \%)$. Also, angling mortality of largemouth bass is twice as great among fish that bleed from 
hooking wounds (Myers \& Poarch 2000); however, bleeding was observed in only $3 \%$ of fish. The low rate of angling mortality observed was thought to be due to a lack of serious hooking wounds in captured fish, which may be related to the type of bait used.

The results provide the first experimental evidence that catch-and-release angling has no effect on growth of largemouth bass. Indirect evidence that catch-andrelease angling does not affect growth of largemouth bass was provided by Quinn (1989) who caught, tagged and released largemouth bass over a 5-year period. He calculated growth rates for tagged fish and compared them with back-calculated growth rates from a sample of untagged, uncaught fish. Quinn (1989) found no difference in growth rates between caught and uncaught fish; however, he did not account for potential mortality of caught fish, which may have influenced his results, nor did he demonstrate that the methods he used to assess growth of caught and uncaught fish were comparable.

Failure to find growth differences between caught and uncaught largemouth bass in this experiment might be related to conditions under which angling occurred and experimental design. Close proximity of largemouth bass and introduced prey in the relatively small experimental tanks may have facilitated feeding by captured fish, which otherwise might have fed less in larger or more natural systems. However, this is unlikely. When prey fish were introduced, largemouth bass fed actively and aggressively until all prey were consumed. Under these circumstances, proximity did not insure that all largemouth bass consumed equal, or any, rations. Also, most fish captured in this study were hooked in locations that result in little injury (Muoneke \& Childress 1994) and that might, therefore, have little effect on feeding. Similarly, the lack of any difference in growth between small and large largemouth bass (among tanks) may be attributable to the experimental design. Largemouth bass were sorted into tanks based on TL to minimize size-related behaviours, which may have allowed smaller fish to feed in the absence of larger, potentially more aggressive, individuals. However, this has no effect on growth differences between caught and uncaught largemouth bass.

Susceptibility to angling is variable in largemouth bass (Burkett, Mankin, Lewis, Childers \& Philipp 1986), with some fish being more vulnerable to capture and recapture than others. Among the 59 fish captured in this study, five $(8.5 \%)$ were recaptured once, and none was recaptured two or more times. Because of the small number of recaptures, potential effects of multiple captures on changes in weight could not be assessed. However, Clapp \& Clark (1989) reported that growth of individual smallmouth bass, Micropterus dolomieu Lacépède, was inversely related to the number of times they were captured. Although, smallmouth bass generally are believed to be more sensitive to angling and handling than largemouth bass (e.g. Hartley \& Moring 1995), we cannot discount the possibility that largemouth bass in heavily fished areas, where individual fish may be subjected to multiple captures, may experience reduced growth attributable to capture and release.

Catch-and-release mortality varies substantially among species (e.g. Muoneke \& Childress 1994) and a number of observations suggests that sublethal effects are at least equally variable. For example, Reingold (1975) found no difference in return rates between migrating steelhead trout, Oncorhynchus mykiss (Walbaum), that had been hooked, played to exhaustion and released compared with those of uncaught fish. In contrast, Philipp, Toline, Kubacki, Philipp \& Phelan (1997) and Kieffer, Kubacki, Phelan, Philipp \& Tufts (1995) found that repeated capture and release of smallmouth and largemouth bass increased the probability that males would abandon nests resulting in lost production of young. The present observations and those of Quinn (1989) suggest catch-and-release angling has little effect on growth of largemouth bass. Similarly, Raat et al. (1997) observed no effect of capture and release on growth of five cyprinids. In contrast, Clapp \& Clark (1989) observed diminished growth in repeatedly captured smallmouth bass and Diodati \& Richards (1996) documented negative effects of catchand-release angling on growth of striped bass, Morone saxatilis (Walbaum). Potential sublethal effects of catch-and-release angling on population characteristics such as growth rates and reproductive output must be better understood in order to understand and predict fishery effects of recreational angling (e.g. Waters \& Huntsman 1986).

\section{Acknowledgments}

We gratefully acknowledge the efforts of $\mathrm{H}$. Cruz, J. Dennis, J. Hoy, J. Ingle, C. Munger and B. Van Zee in collection of largemouth bass. We thank C. Chizinski, P. Chizinski, B. Durham, F. Martinez Jr, K. Offill, S. Sebring and J. Shuck for their assistance. R. Luebke and $\mathbf{J}$. Prentice provided advice on implantation of PIT tags. M. Allen, B. Durham and K. Ostrand commented on this manuscript. This is manuscript number T-9976 of the College of Agricultural Sciences and Natural Resources, Texas Tech University. 


\section{References}

Aas Ø., Thaling C.E. \& Ditton R.B. (2002) Controversy over catch-and-release fishing in Europe. In: T.J. Pitcher \& C. Hollingworth (eds) Recreational Fisheries: Ecological, Economic, and Social Evaluation. Oxford: Blackwell Science, pp. 95-106.

Barnhart R.A. (1989) Symposium review: catch-and-release fishing, a decade of experience. North American Journal of Fisheries Management 9, 74-80.

Burkett D.P., Mankin P.C., Lewis G.W., Childers W.F. \& Philipp D.P. (1986) Hook-and-line vulnerability and multiple recapture of largemouth bass under a minimum length-limit of $457 \mathrm{~mm}$. North American Journal of Fisheries Management 6, 109-112.

Clapp D.F. \& Clark R.D. Jr (1989) Hooking mortality of smallmouth bass caught on live minnows and artificial spinners. North American Journal of Fisheries Management 9, 81-85.

Cooke S.J., Schreer J.F., Wahl D.H. \& Philipp D.P. (2002) Physiological impacts of catch-and-release angling practices on largemouth bass and smallmouth bass. In: D.P. Philipp \& M.S. Ridgway (eds) Black Bass: Ecology, Conservation, and Management. Bethesda, MD, USA: American Fisheries Society, pp. 489-512.

Diodati P.J. \& Richards R.A. (1996) Mortality of striped bass hooked and released in salt water. Transactions of the American Fisheries Society 125, 300-307.

Gustaveson A.W., Wydoski R.S. \& Wedemeyer G.A. (1991) Physiological response of largemouth bass to angling stress. Transactions of the American Fisheries Society 120, 629-636.

Hartley R.A. \& Moring J.R. (1995) Differences in mortality between largemouth and smallmouth bass caught in tournaments. North American Journal of Fisheries Management 15, 666-670.

Hickley P., Marsh C. \& North R. (1995) Ecological management of angling. In: D.M. Harper \& A.J.D. Ferguson (eds) The Ecological Basis for River Management. Chichester: John Wiley \& Sons, pp. 415-425.

Kieffer J.D., Kubacki M.R., Phelan F.J.S., Philipp D.P \& Tufts B.L. (1995) Effects of catch-and-release angling on nesting smallmouth bass. Transactions of the American Fisheries Society 124, 70-76.

McLeay L.J., Jones G.K. \& Ward T.M. (2002) National Strategy for the Survival of Released Line-caught Fish: A Review of Research and Fishery Information. Henley Beach, Australia: South Australian Research and Development Institute, $121 \mathrm{pp}$.

Maitland P.S. (1995) Ecological impact of angling. In: D.M. Harper \& A.J.D. Ferguson (eds) The Ecological Basis for River Management. Chichester: John Wiley \& Sons, pp. 443-452.
Mankin P.C., Burkett D.P., Beaty P.R., Childers W.F. \& Philipp D.P. (1984) Effects of population density and fishing pressure on hook-and-line vulnerability of largemouth bass. Transactions of Illinois Academy of Sciences 77, 229-240.

May R.E. (1972) Evaluation of large scale release programs with special reference to bass fishing tournaments. Proceedings of the Annual Conference of the Southeastern Association of Game and Fish Commissioners 26, 325-329.

Muoneke M.I. \& Childress W.M. (1994) Hooking mortality: a review for recreational fisheries. Reviews in Fisheries Science 2, 123-156.

Myers R.A. \& Poarch S.M. (2000) Effects of bait type and hooking location on post-release mortality of largemouth bass. Proceedings of the Annual Conference of the Southeastern Association of Fish and Wildlife Agencies 54, 39-45.

Pelzman R.J. (1978) Hooking mortality of juvenile largemouth bass, Micropterus salmoides. California Fish and Game 64, 185-188.

Philipp D.P., Toline C.A., Kubacki M.R., Philipp D.B.F. \& Phelan F.J.S. (1997) The impact of catch-and-release angling on the reproductive success of smallmouth bass and largemouth bass. North American Journal of Fisheries Management 17, 557-567.

Plumb J.A., Grizzle J.M. \& Rogers W.A. (1988) Survival of caught and released largemouth bass after confinement in live wells. North American Journal of Fisheries Management 8, 325-328.

Prentice J.A., Hernandez J.L., Shaw C.E. \& Wienecke R.W. (1991) Rapid placement and retention of passive integrated transponder (PIT) tags in grass carp. Proceedings of the Annual Conference of the Southeastern Association of Fish and Wildife Agencies 45, 415-421.

Quinn S.P. (1989) Recapture rates of voluntarily released largemouth bass. North American Journal of Fisheries Management 9, 86-91.

Quinn S. (1996) Trends in regulatory and voluntary catchand-release fishing. In: L.E. Miranda \& D.R. DeVries (eds) Multidimensional Approaches to Reservoir Fisheries Management. Bethesda, MD, USA: American Fisheries Society, pp. 152-162.

Raat, A.J.P., Klein Breteler J.G.P. \& Jansen A.W. (1997) Effects on growth and survival of retention of rod-caught cyprinids in large keepnets. Fisheries Management and Ecology 4, 355-368.

Reingold M. (1975) Effects of displacing, hooking, and releasing on migrating adult steelhead salmon. Transactions of the American Fisheries Society 104, 458-460.

Rutledge W.P. \& Pritchard D.L. (1977) Hooking mortality of largemouth bass captured by artificial lures and natural bait. In: R.A. Barnhart \& T.D. Roelofs (eds) Catch-andrelease Fishing as a Management Tool. Arcata, CA, USA: 
California Cooperative Fishery Research Unit, pp. 103107.

Stickney R.R. (1979) Principles of Warmwater Aquaculture. New York: John Wiley \& Sons, 375 pp.

Waters J.R. \& Huntsman G.R. (1986) Incorporating mortality from catch and release into yield-per-recruit analyses of minimum-size limits. North American Journal of Fisheries Management 6, 463-471.

Wilde G.R. (1998) Tournament-associated mortality in black basses. Fisheries 23, 12-22.

Wilde G.R., Muoneke M.I., Bettoli P.W., Nelson K.L. \& Hysmith B.T. (2000) Bait and temperature effects on striped bass hooking mortality in freshwater. North American Journal of Fisheries Management 20, 810-815.

Wilde G.R., Pope K.L. \& Strauss R.E. (2003) Estimation of fishing-tournament mortality and its sampling variance. North American Journal of Fisheries Management 23, 779786.

Wydoski R.S. (1977) Relation of hooking mortality and sublethal stress to quality fishery management. In: R.A. Barnhart \& T.D. Roelofs (eds) Catch-and-release Fishing as a Management Tool. Arcata, CA, USA: California Cooperative Fishery Research Unit, pp. 43-87. 